\title{
Efficacy of Potassium Octyl Sulphate on Citric Acid Dioproduction
}

\author{
Umesh Prasad Chaurasia* \\ Department of Chemistry, T.R. M. Campus, Birganj, (T. U.) Nepal \\ Email: uchaurasia1000@gmail.com
}

\begin{abstract}
:
The efficacy of potassium octyl sulphate on production of citric acid by some fungal strains such as Aspergillus carbonarius NCIM -2097, Aspergillus saitoi NCIM -2056, Aspergillus usumii NCIM - 2045, Aspergillus wentii NCIM - 2020 and Aspergillus-niger NCIM -2101 has been assessed. It has been found that the fungal strain Aspergillus-niger NCIM -2101 has been found most suitable to give higher yield of citric acid. The micelle; i.e. potassium octyl sulphate under trial has stimulatory effect on bioproduction of citric acid and enhances the yield of citric acid to an extent of $8.579 \%$ higher in comparison to control fermenter flasks, i.e., $8.683 \mathrm{~g} / 100 \mathrm{ml}$ in 12 days of optimum incubation period, $1.8 \mathrm{pH}$ and $30^{\circ} \mathrm{C}$ temperature with $28 \%(w / v)$ molasses solution along with other nutritional ingredients.
\end{abstract}

(Key words: Molasses, citric acid fermentation, potassium octyl sulphate and Aspergillus niger NCIM-2101)

\section{Introduction}

Micelles are spheres of lipids that form in aqueous solutions. In humans, they form from bile salts. These micellar aggregates help transport the digestive products of lipids to the intestine to be absorbed. Also, they are used as detergents.

A micelle is formed when a variety of molecules including soaps and detergents are added to water. The molecule may be a fatty acid, a salt of a fatty acid (soap), phospholipids, or other similar molecules ${ }^{1-}$ 10. The molecule must have a strongly polar "head" and a non-polar hydrocarbon chain "tail". The polar head of the molecule presents itself for interaction with the water molecules on the outside of the micelle. Micelles either accelerates or retards the organic reactions depending on its nature ${ }^{11-20}$. It is assumed that micelles are moderators of enzyme actions in some biological systems ${ }^{21-23}$. There are several known micelles, but a very few micelles have been used in submerged fermentation processes ${ }^{24-31}$. Since micellar effect on fermentation studies especially citric acid fermentation is relatively new and almost unexplored, it needs careful and specific experimentations. In the present investigation the author has made an attempt to study the effect of potassium octyl sulphate on citric acid fermentation by Aspergillus niger NCIM2101

\footnotetext{
* Corresponding author
} 


\section{Experimental Methods}

The influence of potassium octyl sulphate on production of citric acid by Aspergillus niger NCIM2101. The composition of the production medium for production of citric acid by Aspergillus niger NCIM-2101 has been prepared as follows: Molasses: $28 \%(\mathrm{w} / \mathrm{v}), \mathrm{NH}_{4} \mathrm{NO}_{3}: 0.25 \%, \mathrm{KH}_{2} \mathrm{PO}_{4}: 0.25 \%$, $\mathrm{MgSO}_{4} .7 \mathrm{H}_{2} \mathrm{O}: 0.25 \%, \mathrm{pH}: 1.8$

The $\mathrm{pH}$ of the production medium was adjusted to 1.8 by adding requisite amount of $\mathrm{KCl}-\mathrm{HCl}$ buffer solution, and this $\mathrm{pH}$ was also ascertained by a $\mathrm{pH}$ meter. The above composition medium represents volume of a fermenter flask, i.e., "100mL" production medium for production of citric acid by Aspergillus niger NCIM-2101. Now, the same production medium for production of citric acid by Aspergillus niger NCIM-2101 was prepared for 99-fermenter flask, i. e; each contained ' $100 \mathrm{~mL}$ ' of production medium.

The above 99-fermenter flasks were then arranged to 11-sets each comprising of 9-fermenter flasks. Each set was then rearranged in 3-subsets, each consisting of 3-fermenter flasks. The remaining 9fermenter flasks out of 99-fermenter flasks were kept as control and these were also rearranged in 3subsets each consisting of 3 -fermenter flasks.

After preparing the above sets of fermenter flasks M/1000 solution of potassium octyl sulphate was prepared and from the above potassium octyl sulphate solution 1.0, 2.0, 3.0, 4.0, 5.0, 6.0, 7.0, 8.0, 9.0 and $10 \mathrm{ml}$ was added to the fermentation flasks of above 1st to 10th sets respectively. The control fermenter flasks contained no potassium octyl sulphate.

Now, the total volume in each fermenter flasks was made upto $100 \mathrm{~mL}$ by adding requisite amount of distilled water. Thus, the molar concentration of potassium octyl sulphate in 1st, 2nd, 3rd, 4th, 5th, 6th, 7th, 8th, 9th and 10th subsets were approximately as given below:

A $\times 10^{-\mathrm{X}} \mathrm{M}$, i.e.,

$\begin{array}{ll}1.0 \times 10^{-5} \mathrm{M} & 6.0 \times 10^{-5} \mathrm{M} \\ 2.0 \times 10^{-5} \mathrm{M} & 7.0 \times 10^{-5} \mathrm{M} \\ 3.0 \times 10^{-5} \mathrm{M} & 8.0 \times 10^{-5} \mathrm{M} \\ 4.0 \times 10^{-5} \mathrm{M} & 9.0 \times 10^{-5} \mathrm{M} \\ 5.0 \times 10^{-5} \mathrm{M} & 10.0 \times 10^{-5} \mathrm{M}\end{array}$

$\mathrm{A}=\quad$ amount of potassium octyl sulphate, in $\mathrm{ml}$, i.e., $1.0 \mathrm{~mL}$..... to $10 \mathrm{~mL}$.

$\mathrm{x}=\quad$ Molarity of the potassium octyl sulphate solution

The above fermenter flasks were then sterilized, cooled inoculated and incubated at $32 \mathrm{C}$ and analysed after 8,12 and 14 days for citric acid formed ${ }^{31}$. 
J. Nepal Chem. Soc., Vol. 36, 2017

Table - 1 Efficacy of potassium octyl sulphate on citric acid bioproduction

\begin{tabular}{|c|c|c|c|c|}
\hline $\begin{array}{c}\text { Concentration } \\
\text { of micelle used } \\
\mathrm{A} \times 10^{-\mathrm{x}_{M}}\end{array}$ & $\begin{array}{l}\text { Incubation } \\
\text { period } \\
\text { in days }\end{array}$ & $\begin{array}{l}\text { Molasses* } \\
\text { Left unfermented } \\
\text { in } \mathrm{g} / 100 \mathrm{ml}\end{array}$ & $\begin{array}{l}\text { Yields of citric } \\
\text { acid* } \\
\text { in } \mathrm{g} / 100 \mathrm{ml}\end{array}$ & $\begin{array}{c}\% \text { of Citric acid } \\
\text { increased after } \\
12 \text { days }\end{array}$ \\
\hline $\begin{array}{l}\text { Control } \\
\text { (-) Micelle }\end{array}$ & $\begin{array}{l}8 \\
12 \\
14\end{array}$ & $\begin{array}{l}6.295 \\
8.683 \\
7.354\end{array}$ & $\begin{array}{l}5.705 \\
3.318 \\
3.216\end{array}$ & $\begin{array}{l}- \\
- \\
-\end{array}$ \\
\hline $\begin{array}{l}1.0 \times 10^{-5} \mathrm{M} \\
\text { (+) Micelle }\end{array}$ & $\begin{array}{l}8 \\
12 \\
14\end{array}$ & $\begin{array}{l}6.383 \\
8.821 \\
7.720\end{array}$ & $\begin{array}{l}5.619 \\
3.182 \\
3.094\end{array}$ & +1.589 \\
\hline $\begin{array}{l}2.0 \times 10^{-5} \mathrm{M} \\
(+) \text { Micelle }\end{array}$ & $\begin{array}{l}8 \\
12 \\
16\end{array}$ & $\begin{array}{l}6.464 \\
8.934 \\
7.833\end{array}$ & $\begin{array}{l}5.540 \\
3.112 \\
3.024\end{array}$ & +2.890 \\
\hline $\begin{array}{l}3.0 \times 10^{-5} \mathrm{M} \\
(+) \text { Micelle }\end{array}$ & $\begin{array}{l}8 \\
12 \\
16\end{array}$ & $\begin{array}{l}6.521 \\
9.012 \\
8.010\end{array}$ & $\begin{array}{l}5.478 \\
2.989 \\
2.893\end{array}$ & $+3.789^{-}$ \\
\hline $\begin{array}{l}4.0 \times 10^{-5} \mathrm{M} \\
(+) \text { Micelle }\end{array}$ & $\begin{array}{l}8 \\
12 \\
16\end{array}$ & $\begin{array}{l}6.628 \\
9.160 \\
8.059\end{array}$ & $\begin{array}{l}5.372 \\
2.849 \\
2.781\end{array}$ & $+5.493^{-}$ \\
\hline $\begin{array}{l}5.0 \times 10^{-5} \mathrm{M} \\
(+) \text { Micelle }\end{array}$ & $\begin{array}{l}8 \\
12 \\
16\end{array}$ & $\begin{array}{l}6.691 \\
9.243 \\
8.142\end{array}$ & $\begin{array}{l}5.309 \\
2.759 \\
2.663\end{array}$ & $\begin{array}{l}- \\
+6.449 \\
-\end{array}$ \\
\hline $\begin{array}{l}6.0 \times 10^{-5} \mathrm{M}^{* *} \\
(+) \text { Micelle }\end{array}$ & $\begin{array}{l}8 \\
12 \\
14\end{array}$ & $\begin{array}{l}6.823 \\
9.428^{* *} \\
8.326\end{array}$ & $\begin{array}{l}5.179 \\
2.579 \\
2.483\end{array}$ & +8.579 \\
\hline $\begin{array}{l}\text { 7.0x } 10^{-5} \mathrm{M} \\
(+) \text { Micelle }\end{array}$ & $\begin{array}{l}8 \\
12 \\
14\end{array}$ & $\begin{array}{l}6.559 \\
9.057 \\
8.046\end{array}$ & $\begin{array}{l}5.443 \\
2.945 \\
2.856\end{array}$ & $\begin{array}{l}- \\
+4.307\end{array}$ \\
\hline $\begin{array}{l}8.0 \times 10^{-5} \mathrm{M} \\
(+) \text { Micelle }\end{array}$ & $\begin{array}{l}8 \\
12 \\
14\end{array}$ & $\begin{array}{l}6.452 \\
8.909 \\
7.808\end{array}$ & $\begin{array}{l}5.553 \\
3.095 \\
3.080\end{array}$ & $\begin{array}{l}- \\
+2.602 \\
-\end{array}$ \\
\hline $\begin{array}{l}9.0 \times 10^{-5} \mathrm{M} \\
(+) \text { Micelle }\end{array}$ & $\begin{array}{l}8 \\
12 \\
14\end{array}$ & $\begin{array}{l}6.402 \\
8.840 \\
7.739\end{array}$ & $\begin{array}{l}5.599 \\
3.165 \\
3.076\end{array}$ & $\begin{array}{l}- \\
+1.808 \\
-\end{array}$ \\
\hline $\begin{array}{l}10.0 \times 10^{-5} \mathrm{M} \\
\text { (+) Micelle }\end{array}$ & $\begin{array}{l}8 \\
12 \\
14\end{array}$ & $\begin{array}{l}6.345 \\
8.762 \\
7.660\end{array}$ & $\begin{array}{l}5.659 \\
3.327 \\
3.238\end{array}$ & $\begin{array}{l}- \\
+0.909 \\
-\end{array}$ \\
\hline
\end{tabular}

* Each value represents mean of three trials

** Optimum concentration of micelle used

*** Optimum yield of citric acid $(+)$ values indicate $\%$ increase in the yield of citric acid after 12 days.

Experimental deviation $( \pm)$ 1.5-3\% 


\section{Results and Discussion}

The influence of potassium octyl sulfate

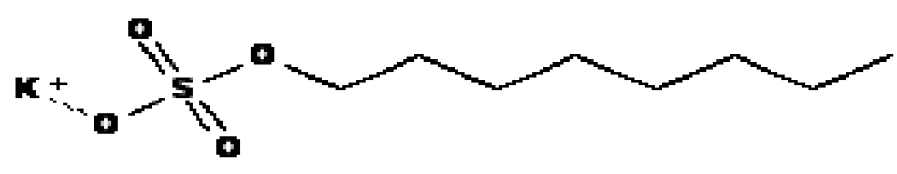

Potassium Octyl Sulfate

The data recorded in the table-1 shows that potassium octyl sulfate also has stimulatory effect on citric acid production by Aspergillus niger NCIM-2101.

The data (vide table-2) reveals that the micelle potassium octyl sulfate stimulates the citric acid fermentation process and enhances the yield of citric acid upto its potassium octyl sulfate concentrations from $1.0 \times 10^{-5}$ to $6.0 \times 10^{-5} \mathrm{M}$. The effect of potassium octyl sulfate on the productivity (yield) of citric acid was gradually in increasing order and attains its best role at $6.0 \times 10^{-5} \mathrm{M}$ where maximum yield of citric acid, i.e., $9.428 \mathrm{~g} / 100 \mathrm{~mL}$ is fetched in 12 days of optimum incubation period which is $8.579 \%$ higher in comparison to control fermentor flask, i.e., $8.683 \mathrm{~g} / 100 \mathrm{~mL}$.

In the second phase of micellar effect the molar concentration, i. e., from $7.0 \times 10^{-5} \mathrm{M}$ to $10 \times 10^{-5} \mathrm{M}$ the production of citric acid has been bit enhanced but the order of citric acid productivity is reverse in respect to increasing molar concentrations of potassium octyl sulfate. However, the citric acid production by Aspergillus niger NCIM-2101 under the influence of each concentration of potassium octyl sulfate used has been stimulating and the yield of citric acid has been found greater than that obtained in the control fermenter flasks. In both the phase the order of productivity and $\%$ of citric acid formed is as below:

\section{Phase- I}

Concentration of potassium octyl sulfate from $1.0 \times 10^{-5} \mathrm{M}$ to $6.0 \times 10^{-5} \mathrm{M}$.

\section{Productivity of citric acid:}

$1.589 \%, 2.890 \%, 3.789 \%, 5.493 \%, 6.449 \%$, and $8.579 \%$

Phase - II

Concentration of potassium octyl sulfate from $7.0 \times 10^{-5} \mathrm{M}$ to $10.0 \times 10^{-5} \mathrm{M}$.

\section{Productivity of citric acid:}

$$
4.307 \%, 2.602 \%, 1.808 \% \text { and } 0.909 \%
$$

Exposure of fungal strain Aspergillus niger NCIM-2101 to potassium octyl sulfate may produce a variety of effects. Depending upon the concentration of potassium octyl sulfate to which fungal strain Aspergillus niger NCIM-2101 were exposed may influence disruption of cells, precipitation of cell protein, inactivation of enzymes and leakage of amino acids from the cells. Although the special mode of action is not very clear, there is a consensus that the lethal effect is associated with physical damage of the membrane structure of the cell surface, which initiates further deterioration. 
J. Nepal Chem. Soc., Vol. 36, 2017

\section{Conclusions}

Thus, it is concluded that potassium octyl sulfate at lower concentrations is stimulatory and at higher concentrations is detrimental for citric acid production by Aspergillus niger NCIM-2101.

\section{Acknowledgement}

The authors are thankful to the Head of the T.R.M. Campus, Tribhuvan University, Kathmandu, Nepal for providing the available research facilities to conduct this research work.

\section{References}

1. J.F. Hochepied and A.P.A. de Oliveira, Porgr. Colloid Polym. Sci. 2004, 125, 68.

2. B.C. Stephenson, A. Goldsipe, K.J. Beers and D. Blankschtein J. Phys. Chem. (B) 2007, 111, 1025.

3. A Goldsipe and D. Blankschtein, Langumir, 2005, 22, 9850.

4. G. Basu Ray, I. Chakraborty S. Ghosh and S.P. Moulik Colloid Polym, Sci., 2007, 285, 457.

5. F.M. Kuni, A.K. Shchekin I. Rusanova and A.P. Grinin, Colloid J., 2004, 66, 174.

6. K. Shivaji Sharma and A.K. Rakshit J. Surf. Deterg., 2004, 7, 305.

7. N. Yoshii, K. Iwahashi and S. Okazaki J. Chem. Phys. 2006, 124, 184901.

8. L. Mailbaum. A.R. Dinner and D. Chandler, J. Phys. Chem. (B), 2004, 108, 6778.

9. T. Chakraborty, S. Ghosh and S.P. Moulik J. Phys. Chem. (B), 2005, 109, 14813.

10. D. P. Tieleman, D. Van der Spoel, H. J. C. Berendsen J. Phys. Chem. 2000, 104: 6380.

11. J. Y. Lion, T. M. Huang and G. G. Chang, J. Chem. Soc. Perkin Trans. 1999, $2,2171$.

12. H. J. Lee and G. G. Chang, J. Colloid Interface, Sci. 1998, 201, 26.

13. A. Mallick, B. Haldar and N. Chattopadhyay, J. Phys. Chem. (B), 109, 2005, 14683.

14. A. Mallick, B. Haldar, S. Maiti and N. Chattopadhyay, J. Colloid Interface, Sci. 2004, 278, 215.

15. S. K. Ghosh, P. K. Khatua, J. K. Ghosh and S. C. Bhattacharya, Spectrochimica Acta, Part A, 2005, 61, 395.

16. S. K. Saha, G. Krishnamoorty and S. K. Dogra, J. Photochem. Photobiol. A: Chem. 1999, 121, 191.

17. G. Krishnamoorty and S. K. Dogra, Chem. Phys. Lett. 2000, 323, 234.

18. M.A. El-Kemary, R. A. Khedr, S. El. -Din and H. Etaiw, Spectrochimica Acta, Part A, 2002, $\mathbf{5 8}, 3011$.

19. S. K. Ghosh and S. C. Bhattacharya, Chem. Phys. Lipids. 2004, 131, 151.

20. S. K. Ghosh and P. K. Khatua, J. Colloid Interface Sci. 2004, 279,

21. Lalan Kumar, S. N. Prasad and S.P. Singh J. Chemtracks, 2000, 2, 79.

22. Anita Singh, S.P. Singh,D. C. Mandal,V. Kumar and B. Singh Vijnana Parishad Anusandhan Patrika, 2004, 47, 367.

23. F. R. Faizi, M. A.Khan, Vijay Kumar P.K. Chauraisa and S. P. Singh, J. Chemtracks, 2004, 6, 59. 
24. F. R. Faizi, K. Ahmad, O. P. Srivastava, Vinita and S.P. Singh J. Chemtracks, 2005 ,7, 117.

25. Geeta Kumari, R. K. Bharti, K. Ahmad, S. K. Srivastava, A. k. Ojha and S. P. Singh J. Chemtracks, 2009, 11(2), 401.

26. Khursheed Ahmad S. K. Srivastava, B. Kumar, R. Kumar O. P. Srivstava and S.P. Singh $J$. Chemtracks, 2010, 12(1), 147.

27. Jai Prakash Kumar and S. P. Singh J. Chemtracks, 2016, 18(1), 57.

28. Pragati Kiran, S. R. K. Singh and S. P. Singh J. Chemtracks, 2016, 18(2), 353.

29. S. K. Sahay and M.K. Roy J. Chemtracks, 2017, 19(1), 103.

30. S. K. Sahay and K.K. Seth J. Chemtracks, 2017 19(2), 201.

31. J. R. Mirror and M. Boulet J. Dairy Science, 1983, 41, 1683. 